\title{
Poësie van die stilte
}

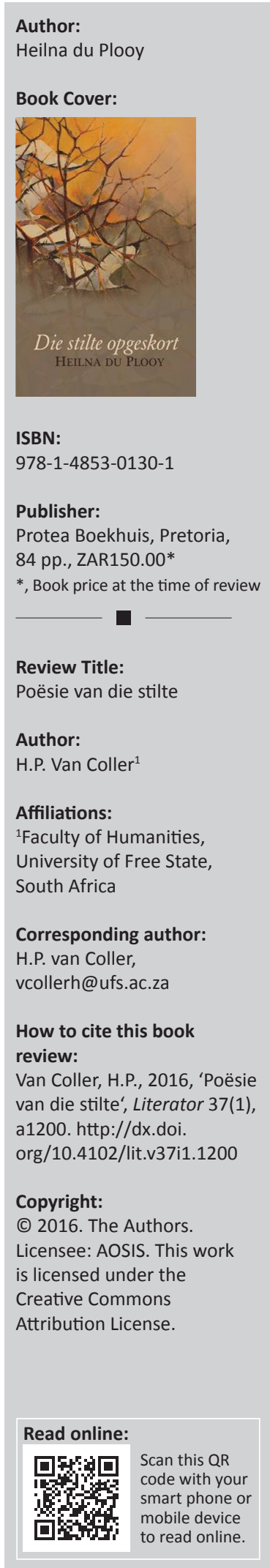

Die bundel met die intrigerende titel Die stilte opgeskort is die gerekende Potchefstroomse akademikus Heilna du Plooy se derde bundel. Du Plooy is onder meer bekend vir haar indringende teoretiese studies oor die narratologie (ook in die poësie), die historiografie én oor die digter T.T. Cloete. Van haar beste werk oor laasgenoemde, mentor en vriend van die digter, handel oor die wyse waarop Cloete in gesprek tree met Nederlandse digters, veral die digter Leopold. In die werk van laasgenoemde Nederlandse digter is daar'n sterk filosofiese inslag aanwesig en'n voortdurende poëtikale besinning oor die aard van die kuns en veral die poësie. Vrae wat voortdurend aan die orde gestel word, is of die poësie 'die amulet teen die vuur' is of kan wees: kan kuns (die poësie) die werklikheid hanteerbaarder maak, die eensaamheid oplos; die uitreik na die 'ander' vergemaklik?

Om Heilna du Plooy as akademikus gelyk te stel met Heilna du Plooy die digter is vanselfsprekend te maklik en selfs metodologies bedenklik: dit is 'n benadering wat per slot van rekening nie soveel verskil van die 'intentional fallacy' nie, een van die doodsondes van die literêre kritiek. Na 'n grondige lees blyk dit egter onomwonde dat daar verskeie parallelle is tussen Du Plooy se akademiese werk en haar poësie. In hierdie bundel word voortdurend besin oor die maak en aard van die kunswerk en die gedig soos in die openingsvers, 'Ewewig'. Die kuns veronderstel ewewig (of balans), en nêrens is dit belangriker nie as in die poësie waar die wit van die bladsy die taal as 't ware inperk en die 'ewewig' opgesluit lê in die aanwesige en afwesige. In die emblematiese reeks 'Jag' is die poësie nie net teenhanger van die beeldende kuns nie, maar is dit ' $n$ poging om die beeldende kuns (en die ewewig daarvan) in poëtiese terme te omskep.

Voorts is daar die besinnende en elegiese aard van die werk waarin nie net die innerlike werklikheid (sterflikheid, liefde, geborgenheid) aan die orde gestel word nie, maar ook die 'eksterne' werklikheid van Suid-Afrika met die verloedering wat hom op soveel gebiede voltrek: letterlik in die verval van stede; moreel in die verval van waardes wat lei tot dronkenskap, geweld, verkragting en afwesigheid van die liefde:

\footnotetext{
Nag

Duisend dronkes wie se lag soos huil klink,

vyftig kapings waar die strate en donker kruis,

honderd lywe wat meegee en breek

onder 'n klip, 'n mes, 'n ander lyf.

En van al die fornikasies wat bedryf

word, is daar miskien wel een vanweë die liefde.
}

Hierdie negatiewe blik op die stad is tipies van die Afrikaanse letterkunde (en veral die prosa). In die poësie kry dit op verskillende manier beslag in die werk van bekende Afrikaanse digters. Daar is onder meer allereers Du Plooy se Potchefstroomse voorganger, die akademikus en teoloog, Totius met sy 'Trekkerswee' (waaroor T.T. Cloete byvoorbeeld indringend geskrywe het), S.J. Pretorius, D.J. Opperman wat van sy stadsgedigte eksplisiet skakel met dié van Totius, en Izak de Villiers, ook 'dominee-digter'. Selfs in die werk van veel meer 'verstedelikte' digters, soos Johann Johl, Johann de Lange en Joan Hambidge is die stad dikwels ook beeld van onthegting, ontnugtering en vereensaming.

'Opgeskort' beteken uitstel. Verskeie resensente wys daarop dat die begrip 'stilte' in die bundel positief voorgestel word. Dat die stille introspeksie van die skeppende mens, die stilte van die poësie sou staan as teenpool van die raserige, eietydse werklikheid soos dit onder meer in onderdele van 'Die pornografie van geweld' beslag kry.

Daar is egter genoeg aanduidings dat die 'stilte' ook kan verwys na die onafwendbare dood. En die motief van sterflikheid kry beslag in verskeie van die (beste) verse in hierdie bundel. Een daarvan is 'Lemoene II' met as motto 'n aanhaling uit 'n gedig van die Groningse digter Rutger Kopland, self weergalose weergewer van weerloosheid en sterflikheid. Die aardse vreugde en 
sintuiglikheid is daar om gedeel te word, immers: 'die tyd vir loop is klein en afgemeet'. Du Plooy se gebruik van assonansies en halfryme is selde in hierdie bundel beter as in die tweede laaste strofe:

$$
\begin{aligned}
& \text { Die vrugte sal sy oopbreek om te deel } \\
& \text { en meededeel ver onder hoë wind. } \\
& \text { Die son en hierdie aarde sal hulle neem } \\
& \text { en eet, uit bekers sap sal hulle drink. }
\end{aligned}
$$

Die slotstrofe: Vertel dan, hart van vlees, die stilte opgeskort,

$$
\text { van somergroei wat in die winter vrugte word. }
$$

waarin die bundeltitel voorkom, is 'n treffende einde van hierdie 'sonnet' wat trekke van die Engelse sonnet toon, maar plek-plek ook daarvan afwyk. Ek dink dit is (dalk) om aan te dui dat 'n gelukkige bestaan waarin die sintuiglike en lyflike belangrik is, hom nie kan voltrek binne orde en reëlmaat nie, soos die keurslyf van die sonnet dalk sou kon laat vermoed. Deur voluit sintuiglik te lewe, word die dood as 't ware uitgestel.

Verset teen die dood neem in die bundel verskeie vorme aan, soos om te reis (kyk na die gedig 'Herfs':

en sy weet sy moet reis

[...] as verweer teen die onbedag woordlose wit

waarin dié stroping haar telkens laat 'tuiskom'), want beweging is juis die teenpool van die stilte (lees ook: inersie) wat met die dood sal aanbreek. Hierdie sintuiglike lewe hou uiteraard verband met skepping wat kunsskepping veronderstel, maar ook enige tasbare nalatenskap soos spoelklippe wat gepak word. En les bes met die erotiese:

Ek wens ook vir myself. Dat ek my man

se lyf soos 'n geheim

steeds naglank kan vashou en dat ek klein

kinders kan omhels

Die wedersydse waardering tussen T.T. Cloete en Heilna du Plooy is wyd bekend, en hy dra selfs twee gedigte aan haar op in sy laaste bundel. Du Plooy se hele bundel is op haar beurt eintlik 'n ode aan Cloete omdat haar poësie deurdrenk is van sy poëtikale denkbeelde en stylgrepe. Dit lê nie net in die verwondering waarmee na die ganse skepping gekyk word en die inherente religieuse aard van die poësie nie. In haar werk is daar ' $n$ diep besef van die klein ruimte, die 'bestemming' waarbinne 'n mens hoort. Dit verklaar ook die wyse waarop familielede en vriende sentraal staan; en die plek van verblyf Potchefstroom - hier ' $n$ tasbaarheid raak, byna soos die Boland (en veral) Stellenbosch in die werk van Lina Spies.

Dalk is die besef van plek (waarin ruimte as 't ware verpersoonlik word) en herkoms (genealogies, maar ook ruimtelik) 'n kenmerk van ouer wordende digters wat voortdurend besig is met vorme van bestekopname. Dit sien 'n mens trouens meermale in die latere werk van Izak de Villiers, Pirow Bekker, Lina Spies, Hennie Aucamp en selfs by die jonger Bernard Odendaal. Net soos by Cloete is daar by Heilna du Plooy 'n opgaan in die natuur wat ook dikwels in erotiese terme beskryf word. Die volgende strofe uit 'Grond en lug' kon netsowel van Cloete self gewees het:

Kyk na die bome. Die wortels hou hulle regop om met die lug te flankeer. Die wind ken elke oksel, soen elke mik, die dwarrels kielie die blare wat giggel en tril. Voor sterk wind buig die boom áf, gee ekstaties mee.

Die status van 'n digter binne 'n bepaalde literêre sisteem word óók gemeet aan die mate waarin hy of sy ander digters beïnvloed het. En ook aan die manier waarop hierdie 'invloed' deur die betrokke digters verwerk is sonder om in blote epigonisme te verval. In die geval van Cloete is dit opmerklik in watter mate sy werk spore gelaat het op, naas dié van Heilna du Plooy, uiteenlopende figure soos Joan Hambidge, Johan Myburgh, Tom Gouws en Bernard Odendaal.

Die verwantskap Cloete / Du Plooy strek verder as bloot die tematiese, maar is ook verstegnies en sluit byvoorbeeld die voorkeur in vir die enumeratiewe, die tipiese sintaktiese isolasie van woorde; die neiging om assonansies, alliterasies én ryme op te stapel:

met die gras aan die brand en die rooi en die rook wat uitsig en insig verwoed teen mekaar opstook ('Ewewig')

én die voortdurende gesprek met ander digters. Heilna du Plooy is in hierdie bundel deurgaans besig om met ander digters in gesprek te tree en soos sy self van Cloete beweer het, daardeur voort te dig op hul werk.

'n Mens kan 'n staalkaart opstel: 'Uit 'n Leidse dagboek' wat nie net gelees kan word as kommentaar op Elisabeth Eybers se tematiese toespitsing op die (Nederlandse) ruimte en die dood nie, maar ook as 'n dialoog met haar. 'Nag' vang heelwat eggo's op van Opperman, 'Ou geboue' van I.D. du Plessis (én Munch) en 'Nanagvers' van Van Wyk Louw ('Beeld van 'n jeug: duif en perd'). Heilna du Plooy het self die werk van die bekende Nederlandse landskapsdigter Willem van Toorn vertaal, en sy elegies narratiewe toon is telkens ook hoorbaar.

Die keersy van die narratiewe vers is altyd die prosaiese en dikwels die anekdotiese triviale. Hierdie bundel ontkom nie altyd hieraan nie. Ook die uitstal van die handgrepe van Cloete raak op die duur net te veel. Maar 'n bundel (lees: enige literêre werk) behoort óók en dalk veral gelees te word binne die poëtikale raam wat dit self daarstel. Daarmee bedoel ek geensins 'n oppervlakkige relativiteit nie. Du Plooy se jongste bundel is die neerslag van 'n hele lewe se vertroude omgang met kuns en literatuur, maar ook vergestalting van 'n ruim en warm gees. Dit kyk soms afkeurend, maar nooit bitter nie; soms met ontsetting, maar nooit moedeloos nie. Uit alles straal daar'n diep religiositeit en 'n eindelose waardering van dit wat aan die menslike bestaan sin gee: voorgangers ('Gemerk'), familie- en gesinslede ('Vierluik'), vriendskappe (soos 'In die streke van die wind' waarin Elize Botha herdenk word), die kuns, maar ook die aardse skoonheid.

Dit is poësie van die stilte eerder as die groot gebaar en tumult, maar daarom nie minder treffend nie. 